\title{
Integrating physical and human geography in the context of mountain development: the Bernese approach
}

\author{
Paul Messerli, Lucienne Rey, Bern
}

Time and again, discussions at the Institute of Geography in Bern regarding the choice of new faculty or debates about how to position ourselves scientifically have inspired us to re-examine our understanding of our discipline. The structural report, for example, which the Institute's board of directors presented to faculty and university directors in 1994, describes our scientific self-conception as follows:

\footnotetext{
«Geography is concerned with humankind's physical-material environment. As such, it is an environmental science. The physical-material environment is analysed according to a dual perspective: as a condition and constraint of humankind and its cultural development; and as a product and result of economic, social, and political processes. This dual perspective requires that the natural sciences as well as the social sciences and humanities be employed to access geography's object of study. The natural science branches of geography examine essential parts of the ecosystem and associated productive, endangering, and limiting factors and processes; these branches use the methodology of the natural sciences and base their research concepts on the systems theories of the natural sciences. The social science and humanistic branches of geography investigate the economically, politically, and socioculturally motivated principles governing our use of the environment, as well as the significance of the physical-material world in the social constitution of the spatial arrangement of society. These branches of geography use the methods of the social sciences and humanities, applying the theories of both in their research concepts.» (DIREKTORIUM DES GEOGRAPHISCHEN INSTITUTS DER UNIVERSITÄT BERN 1994: 1)
}

\section{1 «Man and the Biosphere»: a research programme sets new standards}

This clear declaration of geography in Bern as an environmental science drawing upon two scientific traditions reinforces the conceptual changes that have occurred within the discipline over the years, influenced by international developments in the field and the launch of numerous environmental research programmes.

Particularly decisive for the Institute as a whole was its intensive participation in the national research programme «Socio-economic Development and Ecological Resilience in Swiss Mountain Areas», launched in 1978 as
Switzerland's contribution to the international UNESCO programme «Man and the Biosphere» (MAB). In addition to conceiving and leading the Swiss programme, staff of the Institute were responsible for two of the four study areas in the Swiss Alps (Grindelwald and Aletsch). For almost a decade (1978-86), this programme shaped our collaboration and strengthened our cooperation with other scientific fields and with the authorities and communities in the study areas. Various research teams of the Institute based their research approach on the humanenvironment system schema developed in Bern for the Swiss MAB programme (Fig. 1). The schema itself has gone on to enjoy an international career, as evidenced by the «Global Land Project» of the International Geosphere-Biosphere Programme (IGBP) and the International Human Dimensions Programme on Global Environmental Change (IHDP) - a project that is clearly underpinned by the same basic concept (Fig. 2).

\section{A «Copernican revolution» in geography}

The systems approach postulated in the MAB schema was subsequently widely used at the Institute - especially since systems theories fell on fertile ground in the natural sciences. The approach was steadily expanded in the context of physical geography's landscape-ecology teaching and research concepts. Cultural geography took the important step of adopting a model that reflects the functional differentiation of society and emphasises human agency. Looking back, this gradual transformation - which began in human geography in Anglo-Saxon contexts in the early 1970s and in German-language contexts in 1980 - can be considered a «Copernican revolution» in geography, marking a shift away from a spatially focused discipline and towards an action-focused one. The connection to general systems theory was retained through the fact that human beings - in their everyday creation of geographies constitute their actions in different social systems, each of which obeys its own logic of action. The physical-

This article was originally published in German in the festschrift for the 125th anniversary of the Institute of Geography of the University of Bern: Messerli, P. \& L. Rey (2011): Die Welt in Bern - Bern in der Welt. 125 Jahre Geographie an der Universität Bern. - Jahrbuch der Geographischen Gesellschaft Bern, Band 63, Bern: Geographische Gesellschaft Bern; translated by A. Lannen and M. Thibault; graphics: A. Hermann. 


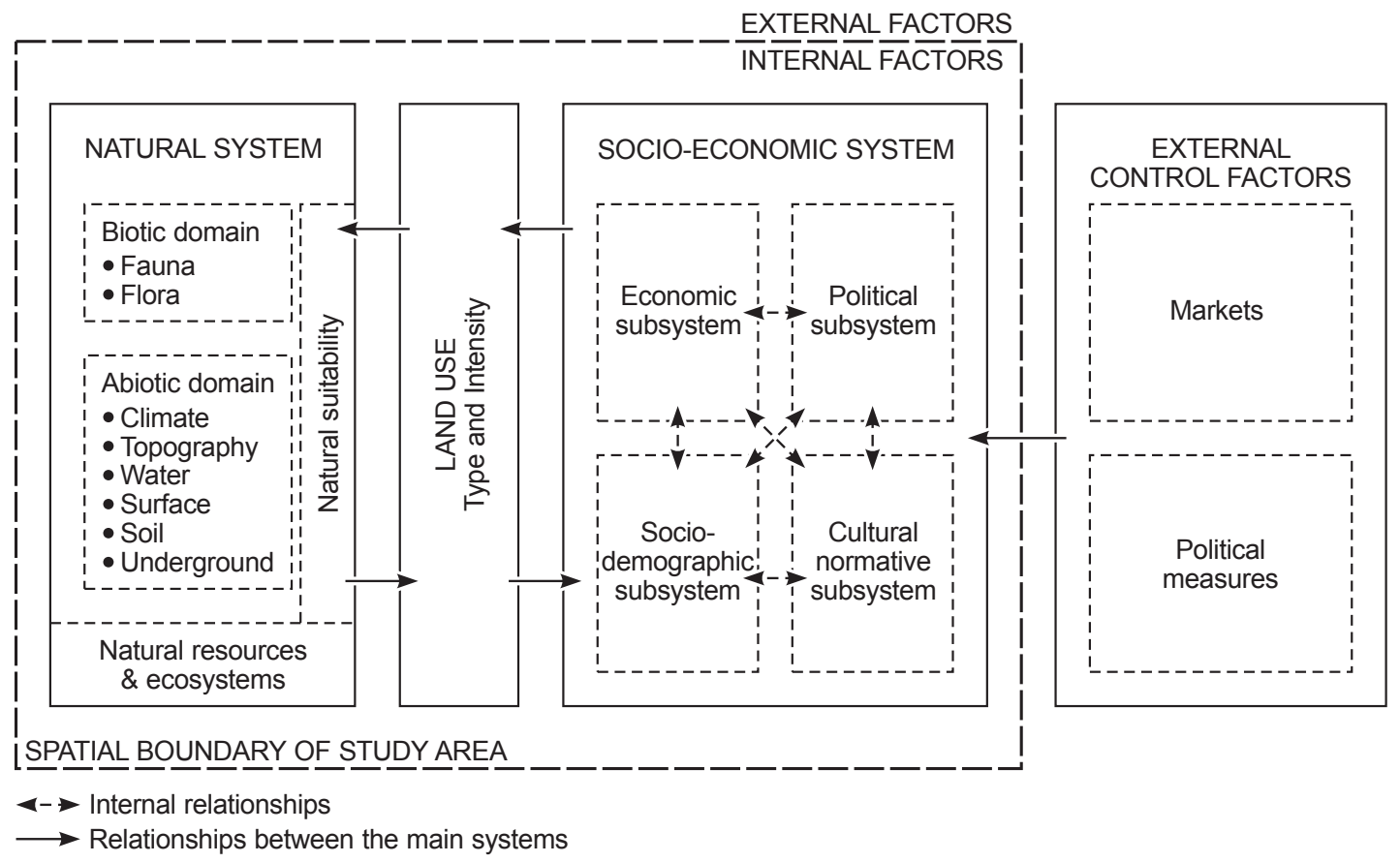

Fig. 1: Representation of a human-environmental system in the context of the Swiss MAB programme Repräsentation eines regionalen Mensch-Umwelt-Systems im Rahmen des schweizerischen MAB-Programms Représentation du système société-environnement dans le cadre du programme suisse MAB Source: Messerli, B. \& P. Messerli 1978: 205 (modified)

material traces of human activity that we encounter are thus sometimes intended but more often unintended consequences of human action; the existing geographies, in turn, are a result of the interaction between the finality of human action and the materiality of the surrounding environment. According to this perspective, the starting point of a geographic analysis of spatial mobility, for example, would no longer be the description of human travel behaviour as an expression of human existence; rather, the starting point would be the question of the importance of spatial mobility for economic, political, or social actors.

\section{The Institute's focus on «sustainable use in mountain areas»}

During the MAB-programme period, we came to the important realisation that a synthesis can only succeed when disciplinary research is guided by collaboratively developed research questions from the outset. This insight is now uncontested in interdisciplinary research. While in the general development of the discipline it led to the abandonment of schemas of regional geography, which followed rules of systematic description and additive logic, in our curriculum and research it paved the way for problem-oriented syntheses at the regional scale. In this way, throughout the 1980s our integrative research expanded beyond the Alps to include mountain areas in East Africa, the Himalayas, the Andes, and the Pamirs. In 1994, these activities finally culminated in the formulation of a new focal point for the Institute, entitled «Sustainable use in mountain areas, against the backdrop of complex environmental dynamics and unequal economic and societal development» (DIREKTORIUM DES GEOGRAPHISCHEN INSTITUTS DER UNIVERSITÄT BERN 1994).

In the introductory preamble to this document, one reads:

«In the current scientific, economic, and political efforts to address complex problems of overdevelopment, underdevelopment, and environmental destruction, two main thrusts may increasingly be distinguished: global strategies that aim to secure international agreements to reduce energy consumption, curb harmful emissions, establish fair 


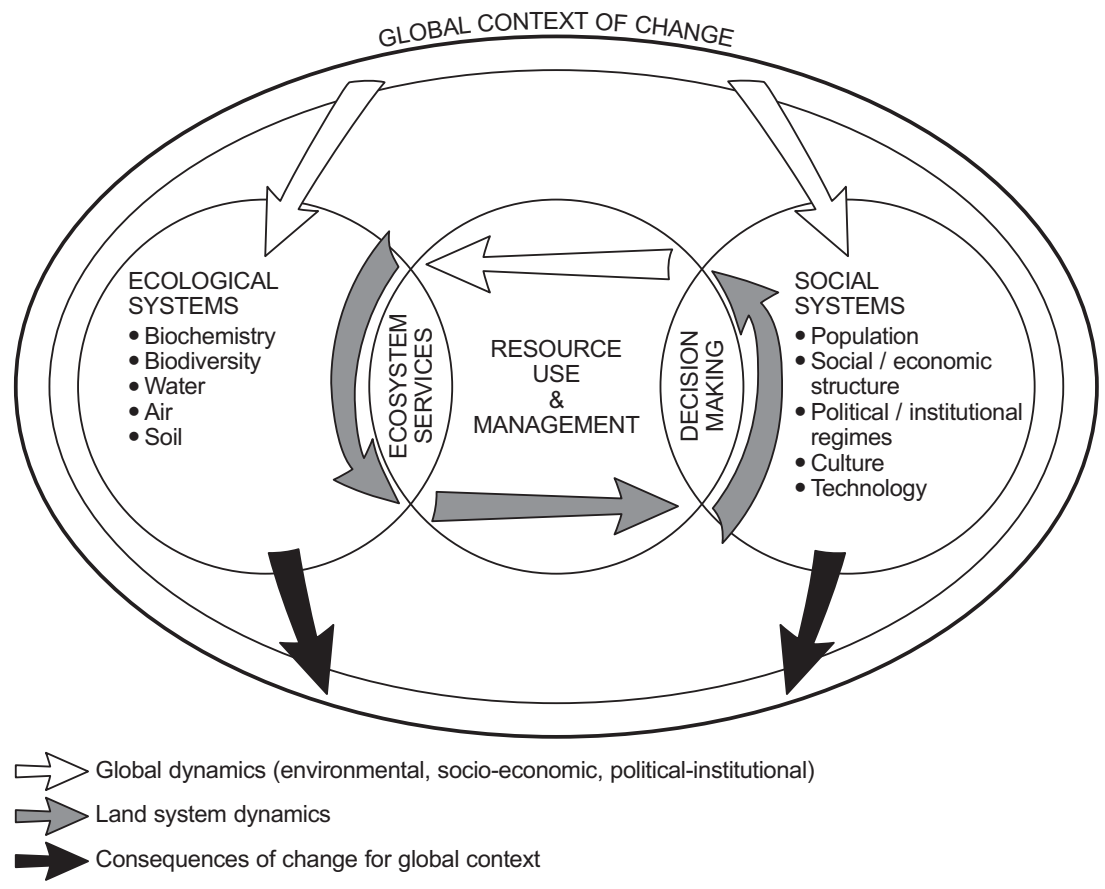

Fig. 2: Basic concept of the Global Land Project of the International Geosphere-Biosphere Programme and the International Human Dimensions Programme on Global Environmental Change Wirkungsgefüge im Globalen Landnutzungsprojekt des Internationalen Geosphären-Biosphären Programms und des Internationalen Programms zur sozialen Dimension globaler Umweltveränderungen Concept de base du Global Land Project de l'International Geosphere-Biosphere Programme et de l'International Human Dimensions Programme on Global Environmental Change Source: Global LAND Project 2005: 17 (modified)

trade relations, and relieve the debt of developing countries; and local and regional initiatives, by contrast, that aim to strengthen people's decision-making competency at this level and expand their scope for action in the area of environmental management and environmental planning. Together, the two strategies form a unit with regard to environmental and development policy; for just as the success of local initiatives depends on national and international safeguards and support, so too is the effective implementation of global agreements contingent upon the existence of local and regional institutions that are capable of action.»

In this way, the founding text of the Institute's new focal point captures, in a problem-oriented manner, what throughout the 1990s in the field of human geography - under the term "glocalisation» - came to be the subject of broad debate about the «scale dependence» of relevant economic, political, and social processes as well as their interdependence. This new per- spective, which required that «regional analyses» be embedded in the process levels of various scale ranges, became the central theme of many of the Institute's research projects.

This focal point and its underlying concept (Fig. 3) inspired research and teaching in equal measure, earning the Institute a reputation as a centre of excellence in mountain research. Even though, based on research funding requirements, it was not possible to commit all of the Institute's research teams to this programme and eventually members of the development and environment group were involved almost exclusively, the programme stands for something very decisive in the last 25 years of the Institute's history: for efforts to establish and to find the «place» of environmental research - the place where the competences of physical geography may be combined with those of human geography in a meaningful, or problem-oriented, manner. That Bern was chosen as 


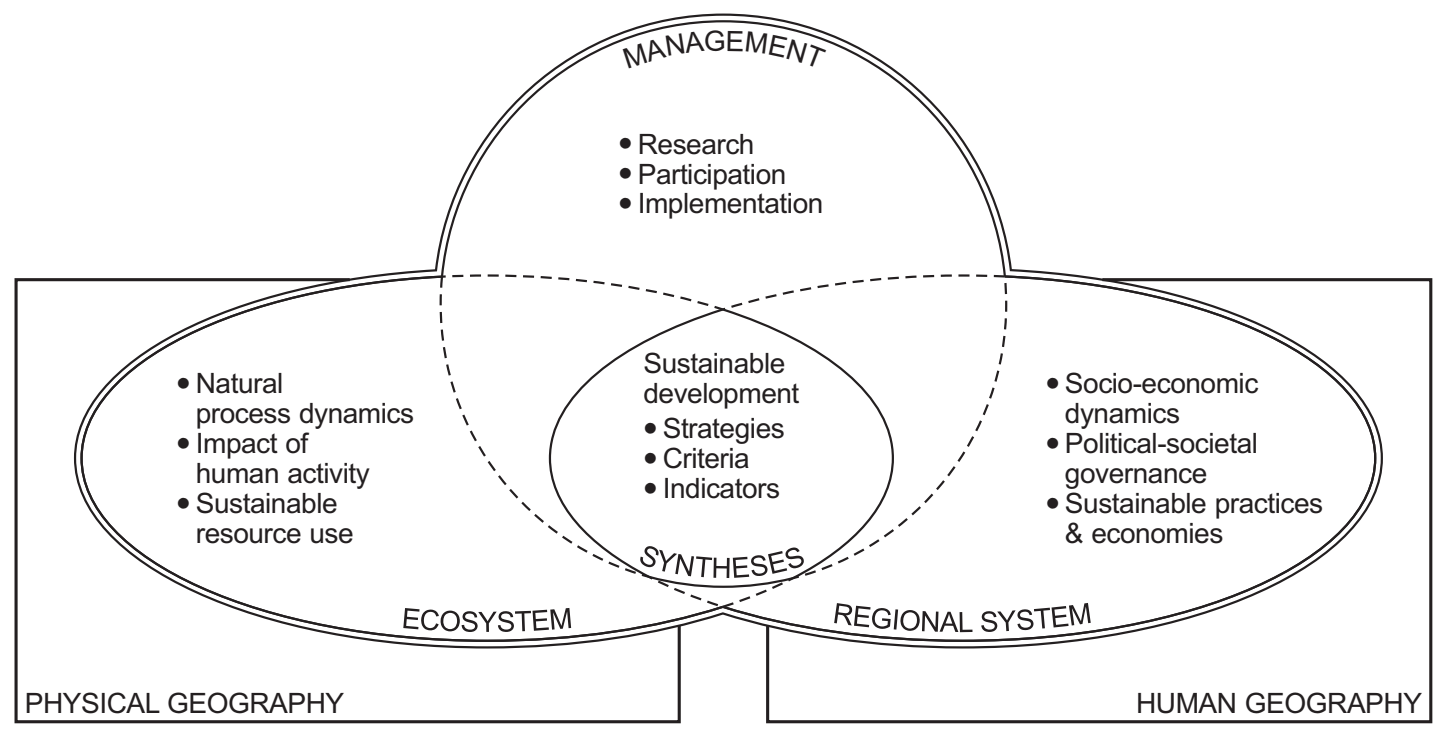

Fig. 3: Integrative concept underlying the Institute's focal point «Sustainable use in mountain areas» Integratives Konzept zum Institutsschwerpunkt «Nachhaltige Nutzung in Gebirgsräumen» Concept général des recherches portant sur «L'usage durable des zones de montagnes» de l'Institut Source: DirekTorium des Geographischen Instituts Der Universität Bern 1994: Anhang C:2 (modified)

the site of the 54th German Geographers Day, whose general focus was «Alpine worlds - mountain worlds: islands, bridges, boundaries», may be also attributed to the Institute's acquired reputation as a leader in such fields of inquiry.

\section{The search for common ground collides with the pursuit of academic recognition}

Standing in the way of the search for common scientific ground was a growing trend causing the two major sub-fields of geography to drift apart. It was the result of a radical turn towards the theories and methodologies of the social sciences among those working in the branches of human geography. The loss of a common understanding of space was a direct reflection of increasing asymmetry between the two sub-fields of geography and their respective objects of study. The study of processes in the layers of the earth - as practiced in physical geography - is divorced from societal processes of perception and valuation. Society's appropriation of the physical-material environment, by contrast, may solely be understood in terms of the inner logic of economic, social, and political, or, ultimately, cultural systems. At the same time, physical geography's depictions of the environment represent one of many sources of information entering into societal processes of perception and appraisal. To this day, however, the frequent demand to move physical geography into the geosciences and human geography into the social sciences has been resisted in Bern: on the one hand, the discipline itself resists such a split; on the other, voices from the faculty and the university have made a strong case for preserving this unusual but historically respected unity.

While it may not have been possible to fully realise the Institute's programme as postulated in 1994, instead resulting in the formation of a competency area led by an interdisciplinary research team - today's Centre for Development and Environment - the collaboration between diverse research teams has certainly advanced at a smaller scale. This has been the case especially in fields where areas of overlap may be readily defined, for example in hazard research.

\section{Pragmatic responses to paradigm shifts}

Looking back at geography's development in Bern over the last 25 years, it becomes clear that - seen against the backdrop of the discipline's evolution internationally - key post-war paradigm shifts were implemented 
with a certain delay in Bern. This applies both to the quantitative-scientistic and the social-scientific «revolutions» that have taken place. One advantage of this delayed response is that it has prevented geography in Bern from undergoing the type of radicalisation that often occurs in the initial phases of any revolutionary upheaval. Two generational transitions at the Institute have been taken as opportunities to react pragmatically to the repositioning of geography. This did not greatly benefit reflexion on the development of the discipline; but it enabled the Institute to participate in ongoing developments on important research fronts and to collaborate on cross-disciplinary projects, which could only be realised in cooperation with other departments.

\section{Source texts on which this article is based}

AutorenKolLeKTIV (1994): Nachhaltige Nutzung in Gebirgsräumen auf dem Hintergrund komplexer Umweltdynamik und ungleicher Wirtschafts- und Gesellschaftsentwicklung. - In: BäTZING, W. \& H. WANNER (Hrsg.): Nachhaltige Naturnutzung im Spannungsfeld zwischen komplexer Naturdynamik und gesellschaftlicher Komplexität. - Geographica Bernensia, P 30, Geographisches Institut der Universität Bern: 149-158.

DiREKTORIUM DES GEOGRAPHISCHEN INSTITUTS DER UNIVERSITÄT BERN (1994): Bericht zur mittelfristigen Planung im Hinblick auf die Rücktritte von K. Aerni und B. Messerli. - Bern: Geographisches Institut der Universität Bern.

Global Land Project - Science Plan \& Implementation Strategy (2005). - In: Global Change Newsletter 63: 16-17.

Messerli, B. \& P. Messerli (1978): Wirtschaftliche Entwicklung und ökologische Belastbarkeit im Berggebiet (MAB Schweiz). - In: Geographica Helvetica 33, 4: 203-210.

Messerli, B. \& P. Messerli (2008): From local projects in the Alps to global change programmes in the mountains of the world: milestones in transdisciplinary research. - In: Hirsch Hadorn, G., Hoffmann-Riem, H., Biber-Klemm, S., Grossenbacher-Mansuy, W., Joye, D., Pohl, C., Wiesmann, U. \& E. Zemp (eds): Handbook of transdisciplinary research. - Heidelberg: Springer: 45-62.

\section{Abstract: Integrating physical and human geography in the context of mountain development: the Bernese approach}

As a hybrid discipline drawing on the natural sciences and cultural studies, geography swings back and forth between convergence and divergence of these two fields and their scientific traditions. There have been many attempts to unite physical geography and human geography in a synthesis. At the University of Bern's Institute of Geography, several important programmes have promoted an integrative approach.

Keywords: paradigm shift, integrative concepts, problem-oriented approach

\section{Zusammenfassung: Nachhaltige Entwicklung in Gebirgsräumen - ein integrativer Schwerpunkt der Berner Geographie}

Die Geographie als hybride Wissenschaft zwischen Natur- und Kulturwissenschaft ist dadurch gekennzeichnet, dass sie zwischen Konvergenz und Divergenz der beiden Wissenschaftskulturen pendelt. Zahlreich sind die Versuche, Physische Geographie und Humangeographie in einer Synthese zu verbinden. Am Berner Institut haben wichtige Programme einen integrativen Ansatz gefördert.

Schlüsselwörter: Paradigmenwechsel, integrative Konzepte, problemorientierter Ansatz

\section{Résumé: Développement durable des espaces de montagne: l'apport de la géographie bernoise}

Discipline hybride traitant tout à la fois des sciences naturelles et culturelles, la géographie alterne entre convergence et divergence entre ces deux champs de recherche et leur tradition scientifique. Plusieurs tentatives de réunir géographie physique et géographie humaine en une seule discipline ont été faites jusqu'ici. Les recherches conduites à l'Institut de Géographie de l'Université de Berne dans le cadre de plusieurs importants programmes vont dans ce sens, en se focalisant sur une approche intégratrice de la géographie.

Mots-clés: changement de paradigme, concepts d'intégration, approche orientée sur un problème

Prof. Dr. em. Paul Messerli, Institute of Geography, University of Bern, Hallerstrasse 12, CH-3012 Bern, Switzerland.

e-mail: mep@giub.unibe.ch

Dr. Lucienne Rey, Militärstrasse 48, CH-3014 Bern, Switzerland.

e-mail: rey.texte@texterey.ch

Manuskripteingang/received/manuscrit reçu le 7.9.2011

Annahme zum Druck/accepted for publication/accepté pour publication: 14.5 .2012 